\title{
POINT OF VIEW
}

\section{Hepatitis $\mathrm{C}$ and fibrosis}

\author{
V. Aguilera and M. Berenguer
}

Service of Digestive Medicine. University Hospital La Fe. Valencia. Spain

Aguilera V, Berenguer M. Hepatitis $C$ and fibrosis. Rev Esp Enferm Dig 2004; 96: 402-414.

\section{INTRODUCTION}

Hepatitis $\mathrm{C}$ virus (HCV) infection is a health problem involving more than 100 million people worldwide. However, despite these high numbers, only a group of infected people will develop serious difficulties from viral persistence. Liver fibrosis is the main complication of chronic $\mathrm{HCV}$ infection, and its eventual outcome -liver cirrhosis- is responsible for liver-related morbidity and mortality (1). The progression rate of fibrosis varies a lot amongst individuals, and its acknowledgment is a determining factor for the assessment of prognosis and treatment needs. Therefore, the search for predictive factors associated with poorer outcome is an interesting work field for the management of these patients.

\section{NATURAL HISTORY OF HEPATITIS C AND ITS PROGRESSION TO FIBROSIS}

Acute $\mathrm{HCV}$ infection results usually in no symptoms and is therefore difficult to diagnose. Overall, it is accepted that only around $15-20 \%$ of patients resolve their infection during the acute stage, whereas infection becomes chronic with a persisting viremia in the remaining 80$85 \%$ of patients (2). Once established, HCV infection results in liver damage with varying degrees of inflammation and fibrosis in most patients. Even though disease

Recibido: 28-01-03.

Aceptado: 03-02-04.

Correspondencia: Victoria Aguilera. Servicio de Medicina Digestiva. Hospita Universitario La Fe. Avda. Campanar, 21. 46009 Valencia. Telf.: 961973118. Fax: 9619731 18. e-mail: mbhaym@teleline.es activity is fluctuating in character, the fibrosis stage seems to be both progressive and irreversible (although controversy has currently arisen regarding this statement). Both the outcome and clinical presentation of chronic infection are variable - while some patients progress towards cirrhosis and/or hepatocellular carcinoma, other individuals simply do not develop complications $(3,4)$. Extant studies on the natural history of this disease are heterogeneous regarding both design and population, and no ideal study has been conducted yet (a study including patients with known infection onset time, and long-term treatment-free follow-up). Unfortunately, most studies are cross-sectional with only a single biopsy, and the few longitudinal studies including 2 biopsies are limited by sample size and a relative bias in patient selection. Therefore, the natural history of hepatitis is still controversial and draws much attention at consensus meetings (5-8). A cross-sectional study by Poynard et al, which included 2,235 patients with chronic hepatitis $\mathrm{C}$, assessed fibrosis progression (Table I). The estimated median progression was 0.133 METAVIR units/year, and time needed for the development of cirrhosis was estimated as 30 years, given a

Table I. Progression of fibrosis in various series

\begin{tabular}{lcccc}
\hline Characteristics & Marcellin & Ghany & Alberti & Poynard \\
\hline Age at infecction & ns & ns & 0.02 & $<0.001$ \\
Gender & ns & ns & ns & $<0.001$ \\
Alcohol & ns & ns & 0.5 & $<0.001$ \\
Necroinflammatory & ns & 0.01 & 0.02 & ns \\
activity & & & & \\
Fibrosis & $*$ & 0.0001 & $*$ & \\
ALT & 0.04 & 0.0001 & 0.001 & \\
\hline
\end{tabular}

ns: not significant. *absent or mild fibrosis in first biopsy. 
linear progression notion is assumed. However, this concept is not currently accepted, and progression is considered to display an asymmetric distribution following at least three progression patterns -rapid, intermediate and slow (9) - and four successive periods for each fibrosis stage since infection (fibrosis progression being slower in early versus advanced stages: 0.056 vs 0.137) (10). Three studies were reported of late, which included two successive biopsies (11-13) and supported this progression model. A systematic review by Freeman et al of 145 studies reporting on the natural history of hepatitis C between 1990 and 2000 included 57 studies in their analysis; they were divided into 4 groups: series of inpatients with chronic liver disease, post-transfusion hepatitis series, cohorts of patients with community-acquired hepatitis, and blood donors. Their major conclusions are summarized as: a) the prevalence of cirrhosis is much higher in inpatients with chronic liver disease and in patients with post-transfusion hepatitis than in patients with community-acquired hepatitis and blood donors (22-24 vs 4-7\%); and b) within 20 years cirrhosis develops in $7 \%$ of patients, and this percentage increases to $40 \%$ within 40 years, this natural history being much more benign than that previously described by other authors (14). This same team has recently analyzed the studies included in the above-mentioned review to develop a predictive model for cirrhosis using mathematical calculations, and combining factors such as gender, alcohol ingestion, increased alanine-aminotransferase (ALT) levels, and histologic activity index. This model may prove useful in daily practice when it comes to decide for or against a given therapeutic option (15).

\section{LIVER BIOPSY: ITS CURRENT ROLE}

Liver biopsy is still the gold standard in assessing fibrosis stage, and repeat biopsy after 3 or 7 years (time lapse still undefined) is the most effective way to assess fibrosis progression. Various histologic assessment systems have been suggested, among which the HAI or Knodell, modified HAI - which provides a more detailed assessment of fibrosis- and Metavir systems stand out; the latter is most widely used in Europe and is characterized by a lesser degree of intra- and inter-observer variation. However, despite its still relevant role in daily practice, its indications are constantly changing partly due to three factors:

1. Difficulties inherent to its technique.

2. Development of biochemical fibrosis markers or fibrosis predictive models.

3. response variability to antiviral treatments.

1. The first, technical-related difficulty is about the fact that this is an invasive procedure associated with non-negligible morbidity, with major complications in around $0.5 \%$ of patients. Secondly, $10-20 \%$ of cases show sample errors, since fibrosis is not always homogeneous in the liver, and samples do not always reflect its extension; the presence of cirrhosis may be underestimated in $15-30 \%$ of patients. Third, there is strong intra- and inter-oberver variability, with concordance being only $60-90 \%$ for fibrosis and less for inflammation (16).

2. Development of non-invasive fibrosis markers: models are currently becoming available that combine serum markers and discriminate between patients with advanced fibrosis (fibrosis bridges or cirrhosis) and mild ( $<$ F2) or absent fibrosis. Table II depicts some recent fibrosis predictive models, including their markers (10,17-24). Generally speaking, however, and due to the absence of validation studies with a relevant number of patients, their clinical use is still scarce (21).

3. Finally, response variability to antiviral therapy in selected subgroups will condition the performance or otherwise of a pre-treatment biopsy. Thus, in the subgroup of patients infected by genotypes 2 and 3 the response rate to antiviral therapy using pegylated interferon plus ribavirin is $80 \%$, and therefore a systematic use of biopsy to estimate pre-therapy histological severity is deemed unnecessary. In contrast, biopsy is still an important part of therapeutic strategy for patients with genotypes other than 2 and 3 , since therapy may be delayed for patients whose fibrosis is nil or limited to portal tracts when poor virologic response variables (genotype, viral load) are present, since this is a prolonged, side-effect-inducing treatment. In contrast, therapy risks should probably be assumed for patients with advanced fibrosis stages or moderate-severe inflammation regardless of virologic variables. These algorithms will most probably change as antiviral drugs improve.

\section{BIOLOGICAL MARKERS OF FIBROSIS}

An alternative approach to liver fibrosis staging is to quantify fibrosis-related products in the serum. Despite the fact that liver fibrosis is a local response, serum levels of fibrogenic citokines, extracellular matrix proteins, and extracellular matrix degradation products may be found in advanced fibrosis stages. Unfortunately, the usefulness of these markers is scarce because of their low sensitivity and specificity. Indeed, one limitation is their lack of organ specificity, as they increase in other clinical conditions. Synthesis and degradation markers include the transforming growth factor $\beta$ (TGF $\beta 1$ ) -the most significant marker of fibrogenesis involved in hepatic stellate cell activation-, aminoterminal type III procollagen propeptide (PIIINP), and carboxyterminal type III and type IV collagen peptide as collagen matrix degradation products. A mammalian protein (YKL-40) belonging in the chitinase family is being researched of late, as it may prove useful in moderate fibrosis and its progression (25). Amongst extracellular matrix components hyaluronic acid and laminin stand out. In the study by McHutchison serum levels below $60 \mathrm{mi}-$ crograms/L had a negative predictive value of $99 \%$ for cirrhosis exclusion (20). Other fibrosis markers include $\alpha_{2}$ macroglobulin and TIMP-1 [tissue inhibitors of metalloprotease]. Alpha-2-macroglobulin is an acute-phase protein 
Table II. Models used in predicting fibrosis

\begin{tabular}{|c|c|c|c|c|}
\hline & No. of patients & Variables analyzed & Diagnostic value & \\
\hline Guechot (17) & 326 & PIIINP, HA & HA as marker of cirrhosis & \\
\hline Oberti (18) & 243 & HA, PT & Both, diagnostic for cirrhosis & \\
\hline \multirow[t]{2}{*}{ Bonacini (19) } & 79 & Platelets, AST/ALT, PT & Combined, fibrosis & \\
\hline & & & bridges and cirrhosis & \\
\hline \multirow[t]{2}{*}{ Poynard (10) } & 500 & Age, platelet count & Combined, for the assessment & \\
\hline & & & of fibrosis bridges and cirrhosis & \\
\hline \multirow[t]{2}{*}{ McHutchinson (20) } & 486 & $\mathrm{HA}$ & Marker of fibrosis & \\
\hline & & & bridges and cirrhosis & \\
\hline \multirow[t]{5}{*}{ Imbert-Bismuth (21) } & 339 & Alpha-2-macroblobulin, & Identification of patients & \\
\hline & & haptoglobin, gamma-globulin, & with or without & \\
\hline & & apolipoprotein A1, GGT, bilirubin, & fibrosis (F0-F1 vs F2-F4) & \\
\hline & & HA, TIMP-1, alpha-2-macroblobulin & using these 5 markers & \\
\hline & & & in combination & \\
\hline \multirow[t]{2}{*}{ Patel (22) } & 416 & HA, TIMP-1, alpha-2- & Identification of patients with & 7.811-3.131.In \\
\hline & & macroglobulin & significant fibrosis (F2-F4) & (No. platelets) \\
\hline \multirow[t]{4}{*}{ Forns (23) } & 476 & Age, cholesterol, & Identification of patients & $+0.781 \cdot \ln (G G T)$ \\
\hline & & platelet count & without fibrosis; & using variables in \\
\hline & & & significant $<\mathrm{f}-0, \mathrm{F1}$, & combination+3.467. \\
\hline & & & & In (age)-0.014 (cholesterol) \\
\hline \multirow[t]{8}{*}{ Chun-Tao Wai (24) } & 270 & AST and platelets & Identification of patients & Significant fibros \\
\hline & & & with significant fibrosis & is: $2.318+0.274$ \\
\hline & & & and cirrhosis & In (AST[/LAN] -0.375. \\
\hline & & & & In (No. platelets [109/L] \\
\hline & & & & Cirrhosis: \\
\hline & & & & $2.411+0.100 . \ln$ \\
\hline & & & & (AST[/LAN])-0.436.In \\
\hline & & & & (No. platelets) \\
\hline
\end{tabular}

that combined with other molecules may help establish significant fibrosis. TIMP-1 and MMP (matrix metalloproteinase) are extracellular matrix degradation enzymes. A combination of some of these markers, rather than each marker on its own, will probably help predict histologic damage and thus become a replacement of liver biopsy.

\section{FIBROGENESIS}

Liver fibrosis results from a biological response to chronic liver damage and subsequent liver remodeling.
In patients with chronic $\mathrm{HCV}$ infection the liver reacts to viral aggression through an inflammatory response, and this is a component of fibrogenesis development. Initially fibrogenesis is a dynamic process that attempts to repair any external aggression-induced damage, and which is characterized by the synthesis of extracellular matrix molecules, a set of proteins (collagen, elastin), glycoproteins (fibronectin and laminin), and proteoglycans organized and interconnected in a tridimensional network. This synthesis is in turn compensated for by fibrinolysis mechanisms in an attempt to destroy this matrix. This non-organ-specific mechanism is initially 
intended to limit an ongoing external aggression -hepatitis $\mathrm{C}$ virus in this case. However it lingers on and eventually results in misbalance between fibrogenesis and fibrolysis in favor of fibrogenesis, and consequently in extracellular matrix accumulation, which leads to an impairment of liver architecture $(26,27)$. In summary, fibrogenesis is initially beneficial but becomes pathologic upon viral persistence.

In hepatitis $C$ fibrosis starts around portal spaces (periportal fibrosis) and extends onto neighboring spaces and centrolobular veins by way of septa and fibrotic bridges (28-30). The final stage of fibrosis is cirrhosis, which is characterized by the presence of fibrous tissue bands that bring together most portal and centrolobular mesenchymal structures, and isolate liver cell nodules.

Fibrogenesis is directly related to hepatic stellate cell activation (31-34). In a healthy liver these cells are found in Disse's space between hepatocytes and the sinusoid wall, and make up 5-8\% of all cells. Their function is retinoid (vitamin A) storage. In the presence of liver damage they undergo activation (transdifferentiation) and acquire a phenotype similar to that of fibroblasts, with a contractile cytoskeleton characterized by the expression of smooth muscle alpha-actin; they see to the production and remodeling of extracellular matrix (34).

Various factors have been involved in liver fibrogenesis, among which the following stand out: cytokines, chemokynes (a family of cytokines capable of inducing cell migration), extracellular matrix receptors, adhesion molecules (ICAM-1, N-CAM), endotelin, norepinephrine, metalloproteinases, metalloproteinase inhibitors, and growth factors. A most relevant growth factor that plays a role in hepatic stellate cell activation is TGF- $\beta$. PDGF (plateletderived growth factor) is also a powerful mitogen for hepatic stellate cells. IL-13 and angiotensin II are both significant cytokines involved in stellate cell activation. CTGF has also been documented in cases of hepatitis C virus infection, and various techniques have shown CTGF increases (33-38) that overall correlate to liver fibrosis (35). Other molecules that play a role in the process of fibrogenesis are those involved in stellate cell migration to damage sites, as is the case with endotelin. IL-10 has been involved in the process of hepatic stellate cell contraction. The activation of ECM-destructive proteinases has been related to $\gamma$-interferon. Other molecules that also seem to play a role in hepatic stellate cell activation include lipid peroxidation by-products (37). Amongst chemokynes, CCL21 is implied in fibrogenesispromoting T-cell recruitment (39). MCP-1 is one of the most potent molecules in recruiting monocytes and macrophages (40). The role of autonomic nervous system cytokines and receptors in fibrogenesis development is a major area currently under study.

Of all these factors, the most clinically relevant ones include: a) those related to fibrogenesis: IL-13, angioten$\sin$ II, TGF- $\beta$, and $\gamma$-interferon; and b) those related to fibrinolysis: interleukin-10.
In summary, fibrogenesis results in the development of fibrosis and a restructuring of the extracellular matrix within hepatic cell tissue, which leads to the lax ECM becoming a reticulated, dense, fibrillar ECM that is more resistant to enzymatic degradation.

\section{FACTORS ASSOCIATED WITH FIBROSIS DEVELOPMENT IN CHRONIC HEPATITIS C}

Cross-sectional and longitudinal epidemiologic studies allowed to define clinical factors associated with the rate of fibrosis development in hepatitis $\mathrm{C}$. These factors may be virus-, host-, and environment-related (Table III).

Regarding viral factors, several studies initially suggested an association between high viral load or genotype 1 infection and aggressive disease. Both these associations have been seemingly ruled out. Regarding viral load, most cross-sectional studies found no correlation between high viremia and greater activity (38). In fact, patients with normal transaminase levels and scant histological activity in biopsy samples may have high viremias. Regarding genotype, recent studies did not confirm the suggested association between genotype 1 and cirrho-

Table III. Factors associated with fibrosis progression in patients with hepatitis $C$

Host-related factors

Alcohol consumption

Age at infection

Gender

$\mathrm{BMI}$

DM

Immunosuppression

$$
\left\{\begin{array}{l}
\text { HIV co-infection } \\
\text { Transplant recipients }
\end{array}\right.
$$

Virus-related factors

Quasispecies*

Histologic factors

Necroinflammatory activity

Fatty liver

Iron overload

Fibrosis

Genetic factors

HLADRB 1 * 11

HLA DQB 1*03

*more studies needed, BMI: body mass index, DM: diabetes mellitus, HIV: human immunodeficiency virus. 
sis or hepatocellular carcinoma outcomes. The longer disease by genotype 1 versus non- 1 probably explains differences amongst studies (41). High viral mutagenicity and its complex composition regarding quasispecies seem to allow this virus to escape the host's immune surveillance system, thus facilitating disease progression. Quasispecies heterogeneity has also been related to greater liver damage (42), and less variability has been seen in patients whose infection resolves, while a high genetic variability exists in cases that evolve towards severe chronic hepatitis. Further studies are needed to define the role of quasispecies in the natural history of hepatitis C.

Host-related factors such as age at infection and gender seem to be most significant for hepatitis progression. Thus, infection at later ages is seemingly associated with more aggressive disease. Studies in patients with post-transfusion hepatitis suggest that at least $20 \%$ of subjects that become infected at 40 or more will develop cirrhosis within 15 years $(43,44)$. However, only $5 \%$ of patients infected via immunoglobulins at younger ages will develop cirrhosis within 20 years following infection $(45,46)$. Similarly, fibrosis progression from 50 years on has been demonstrated to be greater regardless of age at infection $(9,10)$. Finally, donor age in liver transplant recipients seems to play a relevant role in the natural history of recurrent hepatitis C. Male sex has also been associated with poorer outcome in most studies performed. This fact would account for the milder outcomes seen in young women. The reason is unknown. Confounding factors such as body mass index (BMI), alcohol consumption or age at infection may justify this. The host's immune status clearly influences the natural history of hepatitis $\mathrm{C}$. Thus, progression towards cirrhosis is greater in HIV-coinfected patients and in liver transplant recipients with recurrent hepatitis C. In parenteral substance abusers a progression to cirrhosis within 7 years has been described for HIV-positive individuals versus 23 years for HIV-negative individuals $(47,48)$. In patients transplanted for cirrhosis secondary to HCV infection, graft cirrhosis develops in $30 \%$ of subjects at 5 years, and the median time for the development of this cirrhosis is only 12 years $(49,50)$. A greater progression of fibrosis has also been seen in newly transplanted patients. The causes of such worsening have not been elucidated yet, but donor older age and more powerful immunosuppression may likely play a relevant role (51).

Regarding environmental factors, alcohol consumption above $50 \mathrm{~g}$ per day favors greater fibrosis progression, particularly from 10 years after infection on. Even small amounts have been seen to result in greater fibrosis progression (9,10,52-54).

External factors notwithstanding, other factors such as histological factors are associated with greater fibrosis progression, and are only acknowledged after a biopsy is performed. These include necroinflammatory lesions, steatosis, iron overload and fibrosis. Necroinflammatory activity is a dynamic process that fluctuates over time. Its presence and severity in a biopsy sample seem to be related to eventual fibrosis outcome $(12,13)$. Steatosis is a common finding in hepatitis $\mathrm{C}$ biopsies, more common in fact in those infected by genotype 3 and in patients with a high BMI or diabetes mellitus $(55,56)$. Although its pathophysiologic mechanism remains unknown, an association between steatosis severity and fibrosis and/or fibrosis progression has been seen. Iron overload is common though moderate in patients with hepatitis $\mathrm{C}$. Its role in the progression of fibrosis is debatable. It seems to be associated with grater inflammatory activity or high alcohol consumption. Results from clinical studies suggesting that iron overload favors poorer fibrosis outcomes are contradictory (58). Lastly, in patients undergoing several biopsies a predictive factor for fibrosis or cirrhosis development is the presence of previous fibrosis, since fibrosis itself may activate fibrogenesis $(59,60)$.

In addition to virus-, host-, environment-, and histologyrelated factors, individual genetic susceptibility may play an important role regarding the outcome of this disease (61). Thus, it has been reported that alleles HLA DRB1*11 and HLA-DQB $1 * 03$ favor viral clearance and associate with a lower risk of liver lesion development (61-63).

The presence of various polymorphisms in the genes coding for immunoregulating proteins, cytokines or fibrogenic factors is probably important for fibrosis outcome both in patients with chronic hepatitis $\mathrm{C}$ and patients with alcoholrelated liver disease or primary biliary cirrhosis (64).

\section{IS FIBROSIS OR CIRRHOSIS REVERSAL POSSIBLE IN HEPATITIS C?}

The notion of fibrosis or cirrhosis reversibility is not new. Currently, clinical trials on the treatment of HCV infection have renewed interest in this concept, and are favoring a change in the paradigm of hepatology. Experimental animal models of early liver damage have shown that the regression of fibrosis or cirrhosis is feasible as a result of interstitial collagenase or tissue inhibitors of metalloproteinase destroying the extracellular matrix (as a result of hepatic stellate cell activation), as well as the activation of hepatic stellate cell apoptosis $(65,66)$. Fibrosis regression has also been reported in humans, but available studies are few and include diverse liver disease etiologies. In all of them fibrosis/cirrhosis reversal was achieved after the cause of liver disease was eliminated. More than 30 years ago cirrhosis reversibility was already reported in patients with hemocromatosis that had undergone therapy using phlebotomies, as well as in patients with Wilson's disease following treatment with Dpenicillamine $(67,68)$. Fibrosis improvement was also described in patients with autoimmune hepatitis and primary biliary cirrhosis following immunosuppressive therapy (69-71), and evidence exists regarding fibrosis reversibility in patients with chronic hepatitis B and D 
following a regimen of lamivudine (72) and interferon, respectively. Cirrhosis reversibility has been recently described following biliary decompression in patients with chronic pancreatitis and main bile duct stenosis (73).

Whether available antiviral therapies may influence the progression of fibrosis and even lead to fibrosis reversal has been pondered for long regarding patients with $\mathrm{HCV}$ infection. The immunomodulating effects of interferon may help reduce fibrosis $(74,75)$. In addition, acting on the various factors related to worse infection progression -such as a high BMI- also seems to result in improved liver fibrosis and steatosis, as well as in a reduction of hepatic stellate cells (76). In patients with iron overload and HCV infection serial phelobotomies are also associated with biochemical and histologic improvement $(77,78)$. Poynard et al recently described a reduction of fibrosis and even cirrhosis reversal in patients treated with pegylated interferon plus ribavirin. This fact seems to take place particularly in patients who achieve viral clearance, who have a BMI below 27\%, and who are younger than 40 years. These findings suggest that complete reversibility may be obtained for newly established or "young" cirrhosis (79).

In summary, it is possible to revert or reduce fibrosis using antiviral therapy and/or acting on factors associated with greater disease aggressiveness. Further research is needed on the molecular mechanisms of fibrosis regression using antifibrosing agents. However, a complete arrest of fibrosis progression will only be achieved through hepatitis $\mathrm{C}$ virus elimination. It is necessary that better antiviral drugs be developed in order to systematically allow this to happen.

\section{ACKNOWLEDGEMENTS}

This paper was partly supported by a grant from Instituto de Salud Carlos III (C03/02).

\section{REFERENCES}

1. Khan MH, Farell GC, Bit K, Lin R, Weltman M, George J, et al. Wich patients with hepatitis $\mathrm{C}$ develop liver complications? Hepatology 2000; 31: 513-20.

2. Orland JR, Wrigth TL, Cooper S. Acute hepatitis C. Hepatology 2001; 33: 321-7.

3. Pagliaro L, Peri V, Linea C, Cama C, Giunta M, Magrin S. Natural history of chronic hepatitis C. Ital J Gastroenterol 1999; 31: 28-44.

4. Alter HJ, Seeff LB. Recovery, persistence and sequelae inhepatitis C virus infeccion: a perspective on long term outcome. Semin Liver Dis 2000; 20: 17-35.

5. Seef LB. Natural history of hepatitis C. Hepatology 1997; 26 (Supl. 1): $21 \mathrm{~S}-28 \mathrm{~S}$

6. Liang TJ, Rehermann B, Seef LB, Hoofnagle JH. Pathoghenesis, natural history, treatment and prevention of hepatitis C (NIH Conference). Ann Intern Med 2000; 132: 296-305.

7. Alberti A, Chemello L, Benbegnù L. Natural history of hepatitis C. J Hepatol 1999; 31(Supl. 1): 17-24.

8. Seef LB. Natural history of chronic hepatitis C. Manegement of hepatitis C: 2002 (NIH Consensus Statement). http: //consensus nih.gov/116/116cdc_intro-htm.

9. Poynard T, Bedossa P, Opolon P, for the OBSVIRC, CLINIVIRC and DOSVIRC groups. Natural history of liver fibrosis progression in patients with chronic hepatitis C. Lancet 1997; 349: 825-32.
10. Poynard T, Ratziu V, Charlotte F, Goodman Z, McHutchison J, Albrecht J. Rates and risks factors of liver progression in patients with chronic hepatitis C. J Hepatol 2001; 34: 730-9.

11. Marcellin P, Akrémi R, Cazals D, Boyer N, Aupérin A, Vidaud D, et al. Genotype 1 is associated with a slower progression of fibrosis in untreated patients with mild chronic hepatitis C. J Hepatol 2001; 34(Suppl. 1): 159A.

12. Ghany MG, Kleiner DE, Alter HJ, Doo E, Khokhar F, Park Y, et al. Progression of fibrosis in early stages of chronic hepatitis C. Hepatology 2000; 32: 496A.

13. Alberti A, Boccato S, Ferrari A, Benbegnu L, Pontisso P, Noventa F, et al. Outcome of initially mild chronic hepatitis C Hepatology 2001; 34: $225 \mathrm{~A}$.

14. Freeman AJ, Dore GJ, Law MG, Thorpe M, Von Oberbeck J, Lloyd $\mathrm{R}$, et al. Estimating progression to chirrosis in chronic hepatitis $\mathrm{C}$ virus infection. Hepatology 2001; 34: 809-16.

16. Fontana RJ, Lok AS. Non-invasive monitoring of patients with chronic hepatitis C. Hepatology 2002; 36: S57-S64.

17. Guechot J, Laudat A, Loria A, Serfaty L, Poupon R, Giboudeau J. Diagnostic accuracy of hyaluronan and type III procollagen amino-terminal peptide serum assays as markers of liver fibrosis in chronic viral hepatitis C evaluated by ROC curve analysis. Clin Chem 1996; 42: 558-63.

18. Oberti F, Valsesia E, Pilette C, Rousselet MC, Bedossa P, Aube C, et al. Non-invasive diagnosis of hepatic fibrosis or cirrhosis. Gastroenterology 1997; 113: 1609-16.

19. Bonacini M, Hadi G, Govindarajan S, Lindsay KL. Utility of a discriminant score for diagnosing advanced fibrosis or cirrhosis in patients with chronic hepatitis C virus infection. Am J Gastroenterol 1997; 92: 1302-4.

20. McHutchison JG, Baltt LM, de Medina M, Craig JR, Conrad A, Schiff ER, et al. Mesurement of serum hyaluronic acid in patients with chronic hepatitis $\mathrm{C}$ and its relationship to liver histology. Consensus Interferon Study Group. J Gastroenterol Hepatol 2000; 15: 945-51.

21. Imbert-Bismut F, Ratziu V, Pieroni L, Charlotte F, Benhamou Y, Poynard T. Multiviric group. Biochemical markers of liver fibrosis in patients with hepatitis $\mathrm{C}$ virus infection: a prospective study. Lancet 2001; 357: 1069-75.

22. Patel K, Gordon SC, Smith K, et al. A non-invasive panel of serum markers can reliably differentiate hepatitis $\mathrm{C}$ patients with minimal fibrosis from those with fibrosis stages F2-F4. Hepatology 2002; 36: 355A

23. Forns X, Ampurdanes S, Llovet JM, Aponte J, Guinto L, Martínez Bauer $\mathrm{E}$, et al. Identification of chronic hepatitis $\mathrm{C}$ patients without hepatic fibrosis by a simple predictive model. Hepatology 2002; 36: 986-92.

24. Chun-Tao-Wai, Greenson JK, Fontana RJ, Kalbfleisch JD, Marrero JA, Conjeevaram HS, et al. A simple non-invasive index can predict both significant fibrosis and cirrhosis in patients with chronic hepatitis C. Hepatology 2003; 38: 518-26.

25. Johansen JS, Christoffersen P, Moller S, et al. Serum YKL-40 is increased in patients with hepatic fibrosis. J Hepatol 2000; 32: 911-20.

26. Schuppan D. Structure of the extracellular matrix in normal and fibrotic liver: Collagens and glicoproteins. Semin Liver Dis 1990; 10: 1-10.

27. Martínez Hernández A, Amenta PS. Morphology, localization and origin of the hepatic extracellular matrix. In: Zem MA, Reid LM, eds. Extracellular matrix, chemistry, biology and pathobiology with emphasis on the liver. New York: M Dekker, 1993. p. 201-54.

28. Lefkowitch JH, Schiff ER, Davis GL, Perrillo RP, Lindsay K, Bodenheimer HC, et al. Pathological diagnosis of chronic hepatitis C. A multicenter comparative study with chronic hepatitis B. Gastroenterology 1993; 104: 595-603.

29. Scheuer PJ, Ashrafzadeh P, Sherlock S, Brown D, Dusheiko GM. The pathology of hepatitis C. Hepatology 1992; 15: 567-71.

30. Goodman ZD, Ishak. KG. Histopathology of hepatitis $\mathrm{C}$ virus infection. Semin Liver Dis 1995; 15: 70-81.

31. Eng FJ, Friedman SL. Fibrogenesis I. New insights into hepatic stellate cell activation: the simple becomes complex. Am J Physiol 2000; 279: G7-G11.

32. Friedman SL, Roll FJ. Isolation and culture of hepatic lipocytes, Kuffer cells and sinusoidal endothelial cells by density gradient centrifugation with Stracant. Anal Biochem 1987; 161: 207-18.

33. Bedossa P. The cell origin of extracellular matrix proteins. J Hepatol 1993; 19: 1-3.

34. Areson DM, Friedman SL, Bissel DM. Formation of extracellular matrix in normal rat liver: lipocytes as a mayor source of proteoglycan. Gastroenterology 1998; 95: 441-7. 
35. Paradis V, Dargere D, Vidaud M, De Gouville AC, Huet S, Martínez $\mathrm{V}$, et al. Expression of connective tissue growth factor in experimental rat and human liver fibrosis. Hepatology 1999; 30: 968-76.

36. Bedossa P, Poynard T, Mathurin P, Lemaigre ,G, Chaput JC. TGFbeta 1 in situ expression in the liver of patients with chronic hepatitis C treated with alpha interferon. Gut 1993; 34 (Supl. 2): S146S147.

37. Paradis V, Mathurin P, Kollinger M, Imbert-Bismut F, Charlotte F, Piton A, et al. In situ detection of lipid peroxidation products in chronic hepatitis C: correlations with clinical features. J Clin Pathol 1997: 50: 401-7.

38. Zeuzem S, Franka A, Lee JH, Herrmann G, Rüster B, Roth WK. Phylogenetic analysis of hepatitis $\mathrm{C}$ virus islotates and their correlations to viremia, liver function tests and histology. Hepatolgy 1996; 24: 1003-9.

39. Marra F. Hepatic stellate cells and the regulation of liver inflammation. J Hepatol 1999; 31: 1120-30.

40. Boring L, Charo IF, Rollings BJ. MCP-1 in human disease: insights gained from animal models. In: Totowa N, ed. Chemokines in disease: biology and clinical research. 1st ed. Totowa, NJ: Humana, 1999. p. 53-65.

41. López-Labrador FX, Ampurdanes S, Forns X, Castells A, Saiz JC, Costa J, et al. Hepatitis C virus (HCV) genotypes in Spanish patients with HCV infection: relationship between HCV genotype 1b, cirrhosis and hepatocellular carcinoma. J Hepatol 1997; 27: 959-65.

42. Pawlotsky JM, Pellerin M, Bouvier M, Roudot Thoraval F, Germanidis G, Bastie A, et al. Genetic complexity of the hypervariable region 1 (HVR 1) of hepatitis $C$ virus. Influences on the characteristics of the infection and the response to alpha-interferon therapy in patients with chronic hepatitis C. J Med Virol 1998; 54: 256-64.

43. Alter HJ, Seef LB. Recovery, persistence, and sequelae in hepatitis C virus infection: a perspective in long-term outcome. Semin Liver Dis 2000; 20: 17-35

44. Tong MJ, El-Farra NS, Reijes AR, Co RL. Clinical outcomes after transfusion-associated hepatitis C. N Engl J Med 1995; 332: 1463-6.

45. Kenny-Walsh E. Clinical outcomes after hepatitis C infection from contamined anti-D immune globuline. N Engl J Med 1999; 340: 1228-33.

46. Wiese M, Berr F, Lafrenz M, Porst H, Oesen U. Low frequency of cirrhosis in a hepatitis $\mathrm{C}$ (genotipe 1b) single -source outbreak in Germany: a 20 years multicenter study.Hepatology 2000; 32: 91-6.

47. Soto B, Sanchez-Quijano A, Rodrigo L, Leal M, Lissen E. HIV infection modifies the natural history of chronic parenterally adquired hepatitis $\mathrm{C}$ with an unusually rapid progresión to cirrosis. A multicenter study on 547 patients. J Hepatol 1997; 26: 1-5.

48. Di Martino V, Rufat P, Boyer N, Renard P, Degos F, Martinot-Peignoux M, Matheron S, et al. Influence of human immunodeficiency virus coinfection on chronic hepatitis $\mathrm{C}$ in injection drug users: a long term retrospective cohort study. Hepatol 2001; 34: 1193-9.

49. Prieto M, Berenguer M, Rayon M, Cordoba J, Argüello L, Carrasco $\mathrm{D}$, et al. High incidence of allograft cirrosis in hepatitis $\mathrm{C}$ virus genotipe $1 \mathrm{~b}$ infection following transplantation: relationship with rejections episodes. Hepatology 1999; 29: 250-6.

50. Berenguer M, Ferrel L, Watson J, Prieto M, Kim M, Rayon M, et al. $\mathrm{HCV}$-related fibrosis progression following liver transplantation: increase in recent years. J Hepatol 2000; 32; 673-84.

51. Berenguer M, Prieto M, San Juan F, Rayón JM, Martínez F, Carrasco $\mathrm{D}$, et al. Contribution of donor age to the recent decrease in patient survival among HVC-infected liver transplant recipients. Hepatology 2002; 36: 202-10.

52. Wiley TE, Mc Carthy M, Breidi L, Mc Carthy M, Layden TJ. Impact of alcohol on the histological and clinical progression of hepatitis $\mathrm{C}$ infection. Hepatology 1998; 28: 805-9.

53. Pessione F, Degós F, Marcellin P, Duchatelle V, Njapoum C, Martinot-Peignoux M, et al. Effect of alcohol consumption on serum hepatitis $\mathrm{C}$ virus RNA and hitological lesions in chronic hepatitis C. Hepatology 1998; 27: 1717-22.

54. Khan KN, Yatsuhasi H. Effect of alcohol consumption on the progression of hepatitis $\mathrm{C}$ virus infection and riscks of hepatocellular carcinoma in Japanese patients. Alcohol Alcohol 2000; 35: 286-95.

55. Adinolfi LE, Gambardella M, Andreana A, Tripodi M-F, Utili R, Ruggiero G. Steatosis accelerates the progresión of liver damage of chronic hepatitis $\mathrm{C}$ patients and correlates with specific HCV genotype and visceral obesity. Hepatology 2001; 133: 1358-64.

56. Ortiz V, Berenguer M, Rayon JM, Carrasco D, Berenguer J. Contribution of obesity to hepatitis C-related fibrosis progresión. Am J Gastroenterol 2002; 97: 2408-14.
57. Monto A, Alonzo J, Watson J, Grunfeld, Wrigth TL. Steatosis in chronic hepatitis C: Relative contributions of obesity, diabetes mellitus and alcohol. Hepatology 2002; 36: 729-36.

58. Piperno A, Vergani A, Malosio I, Parma L, Fossati L, Ricci A, et al. Hepatic iron overload in patients with chronic viral hepatitis: role of HFE gene mutations. Hepatology 1998; 28: 1105-9.

59. Paradis V, Mathurin P, Charlotte F, Vidaud M, Pooynard T, Hoang C, et al. Histological features predictive of fibrosis in chronic hepatitis $\mathrm{C}$ infection. J Clin Pathol 1996; 49: 1-7.

60. Yano M, Kumada H, Kage M, Ikeda K, Shimamatsu K, Inoue O, et al. The long-term pathological evolution of chronic hepatitis C. Hepatology 1996; 23: 1334-40.

61. Thursz M. Genetic susceptibility in chronic viral hepatitis. Antivir Res 2001; 52: 113-6.

62. Mangia A, Gentile R, Cascavilla I, Margaglione M, Villani MR, Stella F, et al. HLA class II favors clearance of HCV infection and progression of the chronic liver damage. J Hepatol 1999; 30: 984-9.

63. Tillmann HL, Chen DF, Trautwein C, Kliem V, Grundey A, BerningHaag A, et al. Low frequency of HLA-DRB1*11 in hepatitis C virus induced end stage liver disease. Gut 2001; 48: 714-8.

64. Bataller R, North KE, Brenner DA. Genetic polymorphisms and the progression of liver fibrosis: a critical appraisal. Hepatology 2003; 37: 493-503.

65. Mühlbauer M, Bosserhoff A, Hartmann A, Thasler W, Weiss T, Herfarth $\mathrm{H}$. A novel MCP-1 Gene polymorphism is associated with hepatic MCP-1 expression and severity HCV-related liver disease. Gastroenterol 2003; 125: 1058-93.

66. Issa R, Williams E, Trim N, Kendall T, MJP Athur, Reichen J, et al. Apoptosis of hepatic stellate cells: involvement in resolution of biliary fibrosis and regulation by soluble growth factors. Gut 2001; 48: 548-57.

67. Powell LW, Kerr JF. Reversal of "long term intensive venesection therapy. Australs Ann Med 1970; 19: 54-7.

68. Falkmer S, Samuelson G, Sjölin S. Penicillamide -induced normalization of clinical signs and liver morphology and histochemistry in a case of Wilson's disease. Pediatrics. 1970: 45: 260-8.

69. Dufour JF, DeLellis R, Kaplan MM. Reversibility of hepatic fibrosis in autoimmune hepatitis. Ann Intern Med 1997; 19: 54-7.

70. Wanless IR. Use of corticosteroid therapy in autoimmune hepatitis in the resolution of cirrhosis. J Clin Gastroenterol 2001; 32: 371-2.

71. Kaplan MM, Delellis RA, Wolfe HJ. Sustained biochemical and histologic remission of primary biliary cirrhosis in response to medical treatment. Ann Intern Med 1997; 126: 682-8.

72. Kweon YO, Goodman ZD, Dienstag JL, Schiff ER, BrownNA, Burkhardt E, et al. Decreasing fibrogenesis: an immunohistochemical study of paired liver biopsies following lamivudine therapy of chronic hepatitis B. Br J Hepatol 2001; 35: 749-55.

73. Hammel P, Couvelard A, O'Toole D, Ratouis A, Sauvanet A, Flejou $\mathrm{JF}$, et al. Regression of liver fibrosis after biliary drainage in patients with chronic pancreatitis and stenosis of the common bile duct. $\mathrm{N}$ Engl J Med 2001; 344: 418-23.

74. Sobesky R, Mathurin P, Charlotte F, Moussali J, Olivi M, Vidaud M, et al. Modeling the impact of interferon alfa treatment on liver fibrosis progression in chronic hepatitis C: a dynamic view. Gastroenterology 1999; 116: 378-86

75. Shiratori Y, Imazeki F, Moriyama M, Yano M, Arakawa Y, Yokosu$\mathrm{ka} \mathrm{O}$, et al. Histologic improvement of fibrosis in patients with hepatitis $\mathrm{C}$ who have sustained response to interferon therapy. Ann Intern Med 2000; 132: 517-24.

76. Hickman IJ, Clouston AD, Macdonald GA, Purdie DM, Prins JB, Ash $\mathrm{S}$, et al. Effect of weight reduction on liver histology and biochemistry in patients with chronic hepatitis C. Gut 2002; 51: 89-94.

77. Fargion S, Fracanzani AL, Rossini A, Borzio M, Riggio O, Belloni G, et al. Iron reduction and sustained response to interferon-alpha therapy in patients with chronic hepatitis C: results of an Italian multicenter randomized study. Am J Gastroenterol 2002; 97: 1204-10.

78. Yano M, Hayashi H, Wakusawa S, Sanae F, Takikawa T, Shiono Y, et al. Long term effects of phlebotomy on biochemical and histological parameters of chronic hepatitis C. Am J Gastroenterol 2002 ; 97: 133-7.

79. Poynard T, McHutchison J, Trepo C, Lindsay K, Goodman Z, MeiHsiu L, et al. Impact of pegylated Interferon ala-2-b and ribavirine on liver fibrosis in patients with chronic hepatitis C. Gastroenterology 2002; 122: 1303-13. 


\title{
Virus de la hepatitis $\mathrm{C}$ y fibrosis
}

\author{
V. Aguilera y M. Berenguer
}

Servicio de Medicina Digestiva. Hospital Universitario La Fe. Valencia

\section{INTRODUCCIÓN}

La infección por el virus de la hepatitis C (VHC) es un problema de salud que afecta a más de 100 millones de personas en el mundo. No obstante y a pesar de la elevada cifra de afectados, sólo una parte de ellos presentarán problemas graves derivados de la persistencia del virus. La fibrosis hepática es la principal complicación de la infección crónica C y su evolución final, la cirrosis, la responsable de la morbilidad y mortalidad hepática (1). La velocidad de progresión de la fibrosis tiene una gran variabilidad interpersonal por lo que el conocimiento de la misma es determinante en la evaluación del pronóstico y en la necesidad de tratamiento. La búsqueda de factores pronósticos asociados a una peor evolución es, por tanto, un área interesante de trabajo en el manejo de estos pacientes.

\section{HISTORIA NATURAL DE LA HEPATITIS C Y PROGRESIÓN DE LA FIBROSIS}

La infección aguda por el VHC es habitualmente asintomática y, por tanto, difícil de reconocer. En general se acepta que sólo alrededor de un 15-20\% pacientes resuelven la infección durante la fase aguda mientras que en el 80-85\% restante la infección se hace crónica y la viremia persiste (2). Una vez establecida la infección, ocasiona en la mayoría de los pacientes una lesión hepática con diferentes grados de actividad inflamatoria y de fibrosis. Mientras que la actividad tiene un carácter fluctuante, el estadio de fibrosis parece ser progresivo e irreversible (aunque actualmente existen controversias sobre esta aseveración). Tanto la evolución como el espectro clínico de la infección crónica son muy variables, y mientras algunos progresan a cirrosis y/o hepatocarcinoma, otros no desarrollan complicaciones $(3,4)$. Los estudios existentes sobre la historia natural son muy heterogéneos en cuanto a la población estudiada y el diseño, sin existir el estudio ideal (aquel que incluyese pacientes con momento de infección conocido y seguimiento a largo plazo sin tratamiento). Desafortunadamente, la mayoría de los estudios son transversales con una sola biopsia $\mathrm{y}$, los pocos estudios longitudinales en los que se dispone de 2 biopsias, están limitados por el tamaño de la muestra y por el relativo sesgo de selección de los pacientes. Por ello, la historia natural de la hepatitis $\mathrm{C}$ sigue siendo un tema controvertido y es objeto de atención en las sucesivas Conferencias de Consenso (5-8). En el estudio transversal realizado por Poynard y cols. que incluyó un total de 2.235 pacientes con hepatitis crónica $\mathrm{C}$, se evaluó la progresión de la fibrosis (Tabla I). La mediana de progresión calculada fue

Tabla I. Progresión de la fibrosis en diferentes series

\begin{tabular}{lcccc}
\hline Características & Marcellin & Ghany & Alberti & Poynard \\
\hline Edad a la infección & ns & ns & 0,02 & $<0,001$ \\
Sexo & ns & ns & ns & $<0,001$ \\
Alcohol & ns & ns & 0,5 & $<0,001$ \\
Actividad & ns & 0,01 & 0,02 & ns \\
$\quad$ necroinflamatoria & & & & \\
Fibrosis & $*$ & 0,0001 & $*$ & \\
ALT & 0,04 & 0,0001 & 0,001 & \\
\hline
\end{tabular}

ns: no significativo; *no fibrosis o leve en la primera biopsia. 
de 0,133 unidades METAVIR/año, estimándose en unos 30 años el tiempo necesario para el desarrollo de cirrosis, si se asume el concepto de progresión lineal. Sin embargo, este concepto no está aceptado en la actualidad y se considera que la progresión sigue una distribución asimétrica diferenciándose al menos tres patrones de progresión de la fibrosis: rápida, intermedia y lenta (9) y cuatro periodos sucesivos para cada estadio de fibrosis desde la infección (progresión de la fibrosis más lenta en los estadios iniciales que en los avanzados: 0,056 vs 0,137) (10). Recientemente se han publicado 3 estudios en los que se dispone de dos biopsias consecutivas (11-13) que apoyan este modelo de progresión. Una revisión sistemática realizada por Freeman y cols. sobre los estudios publicados sobre la historia natural de la hepatitis C entre 1990 y 2000 recoge 145 estudios y de estos, incluye 57 en el análisis y los divide en 4 grupos diferentes: series hospitalarias de pacientes con hepatopatía crónica, series de hepatitis postransfusional, cohortes de pacientes con hepatitis de la comunidad y donantes de sangre; las principales conclusiones se resumen en: a) la prevalencia de cirrosis es mucho más elevada en pacientes de series hospitalarias con hepatopatía crónica y con hepatitis postransfusional que en pacientes con hepatitis adquirida en comunidad y en donantes de sangre (22-24\% vs 4-7\%); b) el desarrollo de cirrosis a los 20 años ocurre en un $7 \%$ aumentando a un $40 \%$ a los 40 años, siendo esta visión de la historia natural mucho más benigna que la descrita por autores previos (14). Recientemente, este mismo grupo ha analizado los estudios incluidos en el trabajo anterior para desarrollar un modelo de predicción de cirrosis mediante un cálculo matemático, combinando una serie de factores, tales como el sexo, el consumo importante de alcohol, la elevación de la alanino aminotransferasa (ALT) y el índice de actividad histológica. Este modelo puede ser de utilidad en la práctica clínica a la hora de decidir o no una actitud terapéutica (15).

\section{BIOPSIA HEPÁTICA: SU PAPEL EN LA ACTUALIDAD}

La biopsia hepática sigue siendo el patrón de referencia para valorar el estadio de fibrosis y su repetición en 3 ó 7 años (tiempo aún no claramente definido) es el método más eficaz para valorar la progresión de la misma. Diversos sistemas de valoración histológica han sido propuestos, siendo los más aceptados el HAI o Knodell, el HAI modificado que aporta una valoración más detallada de la fibrosis y el sistema Metavir mayormente utilizado en Europa y caracterizado por una menor variabilidad intra e interobservador. Sin embargo, pese a su papel todavía relevante en la práctica clínica diaria, sus indicaciones están cambiando constantemente debido, en parte a tres factores:

1. Los problemas inherentes a la técnica.

2. La aparición de marcadores bioquímicos de fibrosis o modelos de predicción de fibrosis.

3. La variabilidad de respuesta a los tratamientos antivirales.
1. El primer problema inherente a la técnica es que se trata de un procedimiento invasivo asociado a morbilidad no despreciable con complicaciones mayores en torno al $0,5 \%$. En segundo lugar, el error de muestra existe en un $10-20 \%$ ya que la fibrosis no siempre es homogénea en el hígado y la muestra no siempre refleja toda la extensión de la fibrosis, pudiendo incluso llegar a subestimar la presencia de cirrosis en un 15-30\% de los casos. En tercer lugar, existe una gran variabilidad inter e intra-observador con sólo un $60-90 \%$ de concordancia para la fibrosis y menor para la inflamación (16).

2. La aparición de marcadores no invasivos de fibrosis: actualmente están surgiendo modelos que combinan marcadores serológicos y discriminan entre pacientes con fibrosis avanzada (en puentes o cirrosis) o fibrosis leve (< F2) o ausente. En la tabla II se describen algunos de los modelos de predicción de fibrosis más recientes con cada uno de los marcadores incluidos (10,17-24). Sin embargo, y en general debido a la ausencia de estudios de validación con un número importante de pacientes, su aplicabilidad clínica sigue siendo escasa (21).

3. Por ultimo, la variabilidad de respuesta al tratamiento antiviral en determinados subgrupos va a condicionar la realización o no de biopsia pre-tratamiento. Así pues, en el subgrupo de pacientes infectados por los genotipos 2 y 3 , la respuesta al tratamiento antiviral con interfernón pegilado más ribavirina es de un $80 \%$, por lo que la realización de biopsia para estimar la gravedad histológica pre-tratamiento no va a ser necesaria de forma sistemática. Por contra, en pacientes con genotipos distintos al 2 y 3 , la biopsia sigue siendo importante en la estrategia terapéutica a seguir, pues en los pacientes sin fibrosis o limitada a tractos portales, el tratamiento podrá ser diferido si se asocian variables virológicas de mala respuesta (genotipo, carga viral) pues se trata de un tratamiento largo y no exento de efectos secundarios. Por el contrario, en pacientes con estadios de fibrosis avanzada o actividad inflamatoria moderada-importante probablemente se deban asumir los riesgos del tratamiento independientemente de las variables virológicas. Es muy posible que estos algoritmos cambien con la mejora de los fármacos antivirales.

\section{MARCADORES BIOLÓGICOS DE FIBROSIS}

Una aproximación alternativa para evaluar el estadio de fibrosis hepática es determinar en suero productos directamente implicados en el proceso de la fibrosis. Pese a que la fibrosis hepática es una reacción local, pueden encontrarse niveles séricos de citoquinas fibrogénicas, proteínas de la matriz extracelular y productos de degradación de la matriz extracelular en estadios avanzados de fibrosis. Desafortunadamente la utilidad de estos marcadores es escasa al tener una baja sensibilidad y especificidad. En efecto, una de las limitaciones es que no son órgano específicos encontrándose aumentados en otras situaciones clínicas. Entre los marcadores de síntesis y 
Tabla II. Modelos utilizados para predecir la fibrosis

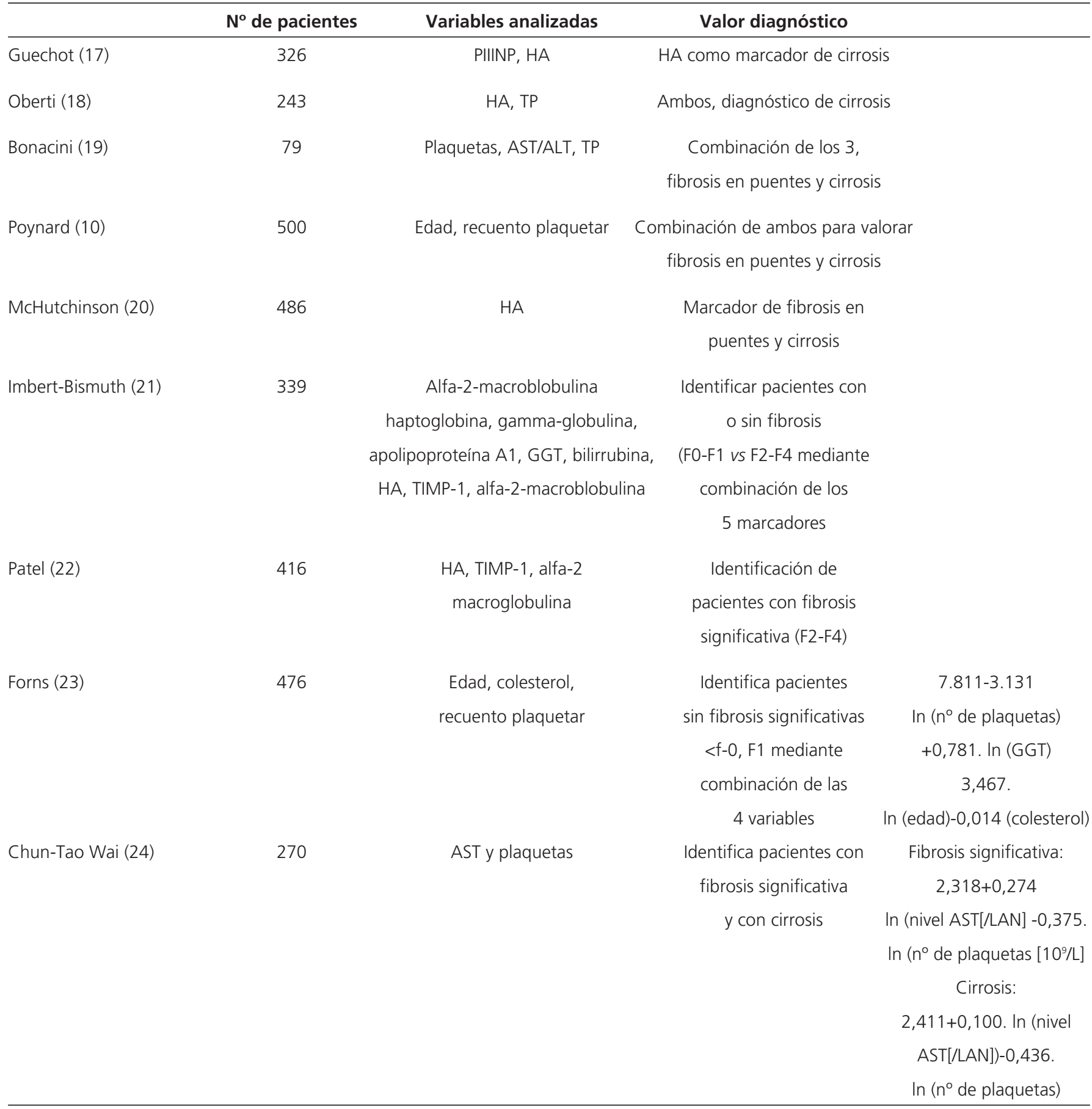

PIIINP: amino terminal propéptido tipo III procolágeno; HA: ácido hialurónico; TP: tiempo de protrombina; TIMP-1: inhibidores del tejido de las metaloproteasas; LAN: límite alto de la normalidad.

degradación estaría el $\beta$ (TGF $\beta 1)$ que es el marcador más importante de fibrogénesis implicado en la activación de las células estrelladas, el amino-terminal propéptido tipo III procolágeno (PIIINP) y el carboxi-terminal propéptido tipo III y tipo IV del colágeno como factores de degradación de la matriz de colágeno. Recientemente se está estudiando la utilidad de una proteína mamífera miembro de la familia citinácea (YKL-40) que tendría cierto valor en la fibrosis moderada así como en la progresión de la misma (25). Dentro de los componentes de la matriz extracelular encontramos el ácido hialurónico y la laminina. En el estudio de Mc Hutchison un nivel sérico de por debajo de 60 microgramos/L tenía un $99 \%$ de valor predictivo negativo para excluir la presencia de 
cirrosis (20). Otros marcadores de fibrosis son la $\alpha_{2}$-macroglobulina y la TIMP-1. La $\alpha_{2}$-macroglobulina es una proteína de fase aguda que puede resultar útil en combinación con otras moléculas para determinar fibrosis significativa. La TIMP-1 [inhibidores de tejido de las metaloproteasas y de las MMP (matriz de las metaloproteasas)] son enzimas de degradación de la matriz extracelular. Probablemente, la combinación de algunos de estos marcadores y no cada uno de ellos en solitario, ayude a predecir la lesión histológica, y puedan ser sustitutivos de la biopsia hepática.

\section{FIBROGÉNESIS}

La fibrosis hepática es el resultado del proceso de respuesta biológico ante el daño hepático crónico y la posterior remodelación hepática. En los pacientes con infección crónica por el $\mathrm{VHC}$, el hígado reacciona a la agresión viral mediante una respuesta inflamatoria, siendo esta reacción uno de los componentes del desarrollo de fibrogénesis. Inicialmente la fibrogénesis es un proceso dinámico que intenta reparar el daño de la agresión externa y que se caracteriza por la síntesis de unas moléculas que constituyen la matriz extracelular, conjunto de moléculas proteicas (colágeno y elastina), glicoproteicas (fibronectina y laminina) y proteoglicanos organizados e interconectados en una red tridimensional. Esta formación se compensa a la vez por mecanismos de fibrinolisis que intentan destruir esta matriz. Este mecanismo no órgano específico que inicialmente tiene como principal objetivo limitar la agresión externa, ante la persistencia del daño, en este caso el virus de la hepatitis $\mathrm{C}$, se perpetúa y finalmente conduce a un disbalance entre fibrogénesis y fibrinolisis a favor de la fibrogénesis y en consecuencia, a la acumulación de matriz extracelular, lo cual conlleva a una perturbación de la arquitectura hepática $(26,27)$. En resumen, la fibrogénesis es inicialmente beneficiosa pero, con la persistencia del virus, se convierte en patológica.

En la hepatitis C, la fibrosis debuta alrededor de los espacios porta (fibrosis periportal) y se extiende hacia los espacios vecinos y las venas centrolobulillares formando septos y puentes fibrosos (28-30). El estadio final de la fibrosis es la cirrosis caracterizada por la existencia de bandas de tejido fibroso que hacen confluir la mayoría de las estructuras mesenquimales portales y centrolobulillares y aíslan nódulos hepatocitarios.

La fibrogénesis está directamente ligada a la activación de las células estrelladas hepáticas (31-34). En el hígado sano, estas células se encuentran en el espacio de Disse, entre los hepatocitos y la pared sinusoidal y representan entre el 5-8\% del total de las células. Su función es el almacenamiento de los retinoides (vitamina A). Ante un daño hepático sufren un proceso de activación (transdiferenciación), adquiriendo un fenotipo similar al de los miofibroblastos, con un citoesqueleto contráctil caracteri- zado por la expresión de la alfa-actina del músculo liso, y se encargan de la producción y remodelación de la matriz extracelular (34).

Se han implicado diferentes factores en la fibrogénesis hepática, entre los que destacan: las citocinas, las quimocinas (familia de las citocinas con capacidad para inducir migración de células), los receptores de la matriz extracelular, las moléculas de adhesión (ICAM-1, NCAM), la endotelina, la noradrenalina, las metaloproteinasas, los inhibidores de las metaloproteinasas y los factores de crecimiento. Entre los factores de crecimiento más relevantes que actúan en la activación de las células estrelladas está el TGF- $\beta$. El PDGF (factor derivado del crecimiento plaquetar) también es un potente mitógeno de las células estrelladas. La IL-13 y la angiotensina II son dos citocinas importantes implicadas en la activación de las células estrelladas. El CTGF, también ha sido bien documentado en el caso de la infección por el virus de la hepatitis $\mathrm{C}$, habiéndose demostrado su elevación por diferentes técnicas (33-38) con una correlación global con la fibrosis hepática (35). Otras de las moléculas que participan en el proceso de la fibrogénesis son aquellas implicadas en la migración de las células estrelladas hacia el lugar del daño, tales como la endotelina. En el proceso de la contracción de las células estrelladas se ha implicado la IL-10. El interferón- $\gamma$ se ha relacionado con la activación de las proteinasas destructoras de la MEC. Otras moléculas que parecen también tener un papel en la activación de las células estrelladas son los productos de la peroxidación lipídica (37). Entre las quimocinas, la CCL21 está implicada en el reclutamiento de linfocitos $\mathrm{T}$ que promocionan la fibrogénesis (39). La MCP-1 es una de las más potentes en el reclutamiento de monocitos y macrófagos (40). El papel de las citocinas y receptores del sistema nervioso autónomo en el desarrollo de la fibrogénesis es una de las áreas de mayor investigación actual.

De todos estos factores, los de mayor relevancia a nivel clínico son aquellos: a) relacionados con la fibrogénesis: el IL-13, la angiotensina-II, el TGF- $\beta$ y el interferon- $\gamma$; y b) relacionados con la fibrinolisis: la interleukina- 10 .

En resumen, la consecuencia de la fibrogénesis es el desarrollo de la fibrosis con reorganización de la matriz extracelular en el seno del tejido hepatocitario, lo cual conduce a la transformación de una MEC laxa en una MEC reticulada y densa de tipo fibrilar mucho más resistente a la degradación enzimática.

\section{FACTORES ASOCIADOS AL DESARROLLO DE LA FIBROSIS EN LA HEPATITIS CRÓNICA C}

Estudios epidemiológicos transversales y longitudinales han permitido definir ciertos factores clínicos asociados con la velocidad de desarrollo de la fibrosis en la hepatitis C. Estos factores están relacionados con el virus, con el huésped o con el ambiente (Tabla III). 
Tabla III. Factores asociados con progresión de la fibrosis en pacientes con hepatitis $C$

Factores del huésped

Consumo de alcohol

Edad a la infección

Sexo

IMC

DM

Inmunosupresión $\quad\left\{\begin{array}{l}\text { Coinfección VIH } \\ \text { Trasplantados }\end{array}\right.$

Factores virales

Cuasiespecies*

Factores histológicos

Actividad necroinflamatoria

Esteatosis

Sobrecarga férrica

Fibrosis

Factores genéticos

HLADRB $1 * 11$

HLA DQB $1 * 03$

*se necesitan más estudios, IMC: índice de masa corporal, DM: diabetes mellitus, $\mathrm{VIH}$ : virus de inmunodeficiencia humana.

Entre los factores virales, inicialmente varios estudios sugerían la asociación entre una carga viral alta o la infección por el genotipo 1 y una enfermedad más agresiva. Estas dos asociaciones parecen estar descartadas en la actualidad. Con respecto a la carga viral, la mayoría de estudios transversales no han demostrado que exista una correlación entre niveles altos de viremia y mayor grado de actividad (38). De hecho, pacientes con transaminasas normales y escasa actividad histológica en la biopsia pueden presentar niveles altos de viremia. En cuanto al efecto del genotipo, los estudios más recientes no han confirmado la asociación sugerida entre genotipo 1 y mayor evolución a cirrosis y hepatocarcinoma. Probablemente la duración más larga de la enfermedad en los genotipos 1 frente a los no-1 permite explicar las diferencias entre los estudios (41). La alta capacidad mutagénica del virus y su compleja composición en cuanto a cuasiespecies parece ser lo que le permite escapar al sistema de vigilancia inmunológica del huésped y hacer progresar la enfermedad. La heterogenicidad en las cuasiespecies también se ha relacionado con un mayor daño hepático (42), habiéndose observado una menor variabilidad entre aquellos pacientes infectados que resuelven la infección y una alta variabilidad genética en aquellos que evolucionan hacia hepa- titis crónica grave. Aun así, se necesitan más estudios para definir el papel de las cuasiespecies en la historia natural de la hepatitis $\mathrm{C}$.

Los factores relacionados con el huésped, tales como la edad de infección y el sexo parecen ser los más importantes en la progresión de la hepatitis. Así, la infección en edades tardías parece asociarse con una evolución más agresiva. Estudios en pacientes con hepatitis postransfusional indican que al menos el $20 \%$ de los sujetos que se infectan con 40 años o más, desarrolla cirrosis en los primeros 15 años $(43,44)$. Sin embargo, tan sólo un 5\% de pacientes infectados a través de inmunoglobulinas en edad joven desarrolla una cirrosis tras 20 años de infección $(45,46)$. Igualmente se ha demostrado que a partir de los 50 años, la progresión de la fibrosis es mayor independientemente del momento de la infección $(9,10)$. Finalmente, la edad del donante en pacientes trasplantados hepáticos parece desempeñar un papel relevante en la historia natural de la hepatitis $\mathrm{C}$ recurrente. El sexo masculino también se ha asociado con una peor evolución en la mayoría de estudios realizados. Este hecho explicaría la evolución más leve de la enfermedad observada en mujeres jóvenes. La razón es desconocida. Quizá factores de confusión, tales como el índice de masa corporal (IMC), el consumo de alcohol o la edad en el momento de la infección justifiquen este hecho. El estado inmunológico del huésped influye claramente en la historia natural de la hepatitis C. Así, existe una mayor progresión hacia cirrosis en pacientes co-infectados con el VIH y en pacientes trasplantados hepáticos con hepatitis $\mathrm{C}$ recurrente. En usuarios de drogas por vía parenteral se ha descrito una progresión a cirrosis en 7 años en los VIH positivo frente a 23 años en los VIH negativos $(47,48)$. En los trasplantados por cirrosis secundaria a VHC, la cirrosis del injerto ocurre en el $30 \%$ a los 5 años y la mediana de tiempo para desarrollar esta cirrosis es de sólo 12 años $(49,50)$. También se ha observado una mayor progresión de la fibrosis en los pacientes trasplantados recientemente. Las causas de este empeoramiento no están aún dilucidadas aunque probablemente la edad mayor de los donantes y la inmunosupresión más potente desempeñen un papel relevante (51).

Entre los factores ambientales, un consumo mayor de $50 \mathrm{~g}$ de alcohol al día condiciona una mayor progresión de la fibrosis, especialmente a partir de los 10 años de infección. Se ha comprobado que incluso pequeñas cantidades pueden producir una mayor progresión de la fibrosis $(9,10,52-54)$.

Al margen de los factores externos, existen otro tipo factores, tales como factores histológicos, asociados a una mayor progresión de la fibrosis, que sólo se reconocen tras la realización de la biopsia. Incluyen las lesiones necroinflamatorias, la esteatosis, la sobrecarga férrica y la fibrosis. La actividad necroinflamatoria es un proceso dinámico fluctuante a lo largo del tiempo. $\mathrm{Su}$ hallazgo e intensidad en la biopsia parece relacionarse con evolución posterior de la fibrosis $(12,13)$. La estea- 
tosis es un hallazgo frecuente en las biopsias de hepatitis C, más frecuente en aquellos infectados por el VHC, genotipo 3 y en pacientes con un IMC elevado o con diabetes mellitus $(55,56)$. Aunque se desconoce el mecanismo fisiopatológico, se ha observado una asociación entre el grado de esteatosis y la fibrosis, y/o progresión de la misma. La sobrecarga de hierro es frecuente pero moderada en los pacientes con hepatitis C. Su papel en la progresión de la fibrosis es discutible. Parece estar asociada a una mayor actividad inflamatoria o a un consumo elevado de alcohol. Los resultados de los estudios clínicos que sugieren que una sobrecarga férrica condiciona una peor evolución de la fibrosis son contradictorios (58). Por último, en los enfermos con varias biopsias, uno de los factores predictivos de desarrollo de fibrosis o de cirrosis es la existencia de una fibrosis instalada previamente, pues la misma fibrosis activaría el proceso de fibrogénesis $(59,60)$.

Además de los factores descritos del virus, ambientales, del huésped e histológicos, parece también existir una susceptibilidad genética en cada individuo que puede desempeñar un papel importante en la evolución de la enfermedad (61). Así, se ha comunicado que los alelos HLA DRB1*11 y HLA-DQB1*03 favorecen el aclaramiento viral y se asocian a un menor riesgo de desarrollar lesiones hepáticas (61-63).

Probablemente, la existencia de diferentes polimorfismos en la codificación de genes de proteínas inmunoreguladoras, citocinas o factores fibrogénicos sea importante en la evolución de la fibrosis tanto en pacientes con hepatitis crónica $\mathrm{C}$ como en aquellos con hepatopatía relacionada con el alcohol o la cirrosis biliar primaria (64).

\section{¿ES POSIBLE LA REVERSIÓN DE LA FIBROSIS O CIRROSIS EN LA HEPATITIS C?}

La reversibilidad de la fibrosis y cirrosis no es un concepto nuevo. Actualmente los ensayos clínicos referentes al tratamiento de la infección por el VHC han hecho resurgir el interés por este concepto y están condicionando un cambio en el paradigma de la hepatología. En los modelos animales experimentales existentes de daño hepático temprano se ha demostrado que la regresión de la fibrosis o cirrosis es posible gracias a la acción de las colagenasas intersticiales o inhibidores tisulares de las metaloproteínas que destruyen la matriz extracelular (resultado de la activación de las células estrelladas) así como por la activación de la apoptosis de las células estrelladas $(65,66)$. La regresión de la fibrosis también ha sido comunicada en humanos en varias ocasiones pero los estudio disponibles son escasos e incluyen etiologías muy diversas causantes de hepatopatías. En todos ellos, la re- solución de la fibrosis / cirrosis se consiguió tras eliminar la causa desencadenante de la enfermedad hepática. Hace ya más de 30 años, se comunicó la reversibilidad de la cirrosis en pacientes afectos de hemocromatosis tras someterse a tratamiento con flebotomías así como en pacientes con enfermedad de Wilson tras tratamiento con D-penicilamida $(67,68)$. También se ha descrito una mejoría de la fibrosis en pacientes con hepatitis autoinmune y cirrosis biliar primaria tras tratamiento inmunosupresor (69-71) y existe evidencia en cuanto a la reversibilidad de la fibrosis en pacientes con hepatitis crónica B y D tras tratamiento con lamivudina (72) e interferón respectivamente. Recientemente se ha descrito la reversibilidad de la cirrosis tras descompresión biliar en pacientes con pancreatitis crónica y estenosis de la vía biliar principal (73).

En los pacientes con infección por el virus VHC se postula desde hace tiempo si los tratamientos antivirales disponibles pueden influenciar la progresión de la fibrosis e incluso conducir a la regresión del proceso. Los efectos inmunomoduladores del interferón podrían contribuir a una disminución de la fibrosis $(74,75)$. Además la actuación sobre los diversos factores relacionados con una peor progresión de la infección, tales como un IMC elevado, también parece seguirse de una mejoría en la fibrosis hepática y la esteatosis así como una disminución de las células estrelladas (76). En pacientes con sobrecarga férrica e infección por VHC, las flebotomías seriadas también se acompañan de una mejoría bioquímica e histológica $(77,78)$. Recientemente Poynard y cols. han descrito una disminución de la fibrosis e incluso reversibilidad de la cirrosis en pacientes tratados con interferón pegilado y ribavirina. Este hecho parece evidenciarse sobre todo en pacientes que consiguen el aclaramiento viral, tienen un IMC inferior al $27 \%$ y son menores de 40 años. Estos hallazgos sugieren que es posible obtener la reversibilidad completa de la cirrosis establecida recientemente o "cirrosis joven" (79).

En resumen, es posible revertir o disminuir la fibrosis mediante tratamientos antivirales y/o actuando sobre aquellos factores asociados a una mayor agresividad de la enfermedad. Es necesario continuar investigando sobre los mecanismos moleculares de regresión de la fibrosis con agentes antifibrosantes. La detención completa de la progresión de fibrosis sólo se conseguirá, no obstante, con la eliminación del virus de la hepatitis C. Para que esto ocurra de forma sistemática, es preciso descubrir mejores fármacos antivirales.

\section{AGRADECIMIENTOS}

Este trabajo ha sido realizado en parte con la ayuda de la Beca del Instituto de Salud Carlos III (C03/02). 